\title{
Distant Learning: The Experiences of Brazilian Schoolteachers during the COVID-19 School Closures
}

\author{
Clarisse Halpern ${ }^{1}$ \\ Florida Gulf Coast University
}

\begin{abstract}
The COVID-19 pandemic has imposed several challenges to education, especially with the shift from traditional face-to-face to distance learning, affecting teaching and learning worldwide. While distance learning seemed to favor children of affluent families, students of low socioeconomic families faced additional challenges, like the lack of adequate resources to attend online classes and continue their education. Thus, in this study, schoolteachers' experiences adapting their instructional strategies to distance learning were investigated. A qualitative case study examined and compared the experiences of a public-school and a private-school teacher with distance learning in Brazil during the COVID-19 pandemic school closures. The cases give insight into the strategies used and challenges experienced by the participants while attending to different student populations' needs: marginalized and more affluent. Thematic analysis of the aggregated data indicated the participants' similar distant teaching and learning experiences (disconnected interactions with their students) and distinct perspectives and commitments to teaching and their use of technology in education. Recommendations and implications for educators, administrators, and policymakers are included.
\end{abstract}

Keywords: COVID-19, pandemic, distance learning, teacher experience. qualitative case study.

Beginning March 2020, the COVID-19 pandemic has imposed several challenges to education worldwide, with classes transitioning from traditional face-to-face instruction to distance learning as a measure to protect students from the risk of infection and reduce the transmission of the virus (Viner et al., 2020). Schools from over 190 countries were closed, affecting $90 \%$ of the student population globally. As the pandemic continued, the consequence of undefined school calendars, uncertainties about schools reopening, and the impacts of interrupted schooling pile up as well as concerns for long-term adverse effects to millions of children, particularly those of vulnerable populations (UNESCO, 2020).

In Brazil, where over $77 \%$ of primary schools are public, 48.5 million students of nearly 181 thousand primary schools were affected by school closures (Instituto Nacional de Estudos e Pesquisas Educacionais Anísio Teixeira [INEP], 2019). The challenges of unprecedented times during the pandemic highlighted existing inequalities in the country, such as homes without adequate space to study, no basic sanitation, lack of computers/notebooks, and restricted to no internet access. Also, 83\% of school teachers feel unprepared to use the internet for education, lacking proper technology education and training to work with distance learning (Tenente, 2020). Indeed, the fact that teachers are consumers of technology does not warrant their ability to translate their skills into instructional strategies (Modelski et al., 2019).

${ }^{1}$ Corresponding Author E-Mail: clari_halpern@ hotmail.com 
In Brazil, approximately 4.8 million students, ages nine to 17 , had no internet access at home during the pandemic, which prevented their access to distance learning during the isolation measures (UNICEF Brasil, 2020). Also, families faced challenges with the internet connection at home; amongst the lowest socioeconomic student population in the country, $71 \%$ relied on mobile phone $3 \mathrm{G}$ access or limited wi-fi connection, while $3 \%$ owned a computer/notebook, which restricted considerably the students' ability to access content online (Tenente, 2020; Tokarnia, 2020b). This scenario increased the inequalities concerning access to fundamental rights, such as education, health, protection, and social participation in Brazil (UNICEF Brasil, 2020). Specifically, while $39 \%$ of urban public-school students in the country did not own a computer or a tablet, that was the reality of only $9 \%$ of private school students. In fact, before the COVID-19 pandemic, $14 \%$ of Brazilian public schools offered any sort of distance learning platform to their students (Oliveira, 2020). Notwithstanding, schoolteachers were faced with the challenge of teaching online to give continuity to their students' education. Thus, it was particularly relevant to investigate and compare the case of Brazilian schoolteachers - of private and public schools - and their in-depth experiences transitioning from traditional to distance learning, adapting their strategies to attend to their students' needs.

\section{Distance Learning in Brazil}

Distance learning in Brazil - as known as EaD, that is, Ensino a Distância, in Portugueseis considered an educational approach that uses information and communication technologies (ICTs) to promote educational activities between teachers and students unbounded by time or space. As regulated by the Federal Decree 5.622, distance learning can be applied from primary and adult education, to special education, professional and higher education (Brasil, 2005).

Souza (2008) praised distance learning as an inevitable model in the $21^{\text {st }}$ century because of its ability to add new infinite knowledge to science and humanity globally. In Brazil, distance learning is said to bridge the gap of the inadequate distribution of teachers across the country. Moreover, distance learning and the ICTs are believed to allow students to become explorers and researchers, using online navigation to seek individualized knowledge that will, ultimately, result in better educational and job opportunities for those who know how to use it (Guimarães, 2010).

Nonetheless, the negative aspects of distance learning include the growing inequality in education, particularly when comparing students of different socioeconomic statuses in public and private schools across the country, with varying knowledge and access to technology and to the internet (Moraes, 2011). Further, distance learning seems to favor the fragmentation and precariousness of teaching and learning processes, resulting in education commodification (Patto, 2013). In this view, instead of the ICTs become a means to an end - that is, education - they become ends in themselves with an excessive emphasis on skills to use technology rather than learning (Moraes, 2010).

In this sense, distance learning tends to be praised without much criticism, with rhetoric that distance learning is a worldwide phenomenon that improves education, guarantees the improvement of life and employability, and is making major progress in Brazil (Patto, 2013). Thus, students who, for any reason, do not adapt to this mode of learning are added to the statistics of drop-out students, with claims that distance learning has a high-level of demand and quality; in other words, the students, not distance learning, are blamed for school drop-outs and low academic performance (Moraes, 2010; Moraes, 2011; Patto, 2013).

However, the inevitability of online and distance learning during the COVID-19 pandemic required more collaboration among educators, students, and their families. At the same time, it revealed that neither schools nor teachers were prepared for this transition. Schools did not have 
the technological support to implement distance learning, and educators had not been appropriately trained to teach online (Lu, 2020; Lynch, 2020).

\section{Method}

A qualitative case study approach was applied to investigate the concrete, real-life experiences of Brazilian schoolteachers with remote teaching during the COVID-19 pandemic school closures (Stake, 2005; Yin, 2005). As case studies can be "an individual, a small group, an organization, or a partnership" (Creswell \& Poth, 2018, p. 96), a purposive sample of two Brazilian schoolteachers was selected to share their perspectives and experiences teaching remotely during the COVID-19 pandemic (Patton, 2002). The two schoolteachers worked at public and private schools awarded for best practices transitioning to distance learning during the pandemic. Besides, following Stake's (1995) assertions, the cases were instrumental because they exemplified the phenomenon under investigation. Their accounts provided in-depth perspectives of the teachers' experiences and challenges in the contemporary context (Merriam, 1998) of teaching students remotely during the COVID-19 pandemic school closures in Brazil.

The research questions guiding this study were the following: What are Brazilian schoolteachers' experiences with distance learning during the COVID-19 pandemic? In what ways did the schoolteachers adapt their lessons to teaching remotely to attend to their students' needs during the COVID-19 pandemic school closures? What were the similarities and differences between public and private school teachers' experiences teaching online during the pandemic?

\section{Data Collection Process}

In order to increase the study's credibility and trustworthiness, as well as to help reveal the meanings of the participants' experiences teaching online during the COVID-19 pandemic, multiple sources of data were collected and combined. The data collection process included indepth interviews, documents (lesson plans and curricular guidelines), artifacts (online videos, exercises, and apps), and observational notes (Creswell \& Poth, 2018; Stake, 2005). Before the data collection process, the participants signed an Informed Consent Form authorizing their participation in the study, ensuring their right of non-response, non-participation, and warranting the confidentiality of their identities and protection of the information shared. Thus, henceforth, the participants will be referred to by pseudonyms (Julio and Henrique), and the names of the schools where they work will be omitted (Creswell, 2014).

The lesson plans, homework exercises, and online video-lessons collected were also analyzed; they illustrated how the teachers organized and planned the activities provided to the students and revealed the interactions between teachers and students virtually. The in-depth interviews were conducted online in July and August 2020 to dig deeper into Julio's and Henrique's experiences, feelings, challenges, and attitudes about distance learning during the COVID-19 pandemic (Denzin, 1989). The interviews allowed the researcher to collect more thoughtful and detailed responses from Julio and Henrique in a trusting, social conversation environment. In addition, personal communications via online mobile messaging applications were used to gather follow-up information about the data shared. This allowed the participants to respond to additional questions using voice notes, videos, texts, and visual images to exemplify their answers and experiences (Roller \& Lavrakas, 2015). Finally, the observational notes helped give strength to the interview data and materials collected, resulting in a more detailed description of the cases (Yin, 2005). 


\section{Data Analysis Procedures}

The interviews, observational notes, documents, and personal communications were conducted and exchanged in Portuguese, the participants' and the researcher's native language. Thus, these data had to be translated from Portuguese to English before being analyzed. Julio's online videos and homework did not need translation as they were produced and edited in English, the subject-matter he taught at the time of the study.

Thematic analysis was used as it is both a descriptive and interpretative procedure, in which a central aspect is the researcher's ability to use her "subjectivity and personal insight to interpret data for theme development" (Vaismoradi \& Snelgrove, 2019, p. 8), capturing the core of the phenomenon under investigation. Consistent with Braun and Clarke's (2006) and Nowell and colleagues' (2017) assertions, the thematic analysis was conducted as an iterative, reflective, and non-linear process. As the researcher got familiarized with the data collected, initial codes were generated capturing the richness of the phenomenon (Boyatzis, 1998). This process was followed by the refinement of the relevant codes into themes (Braun \& Clarke, 2006) that "capture[d] and unif[ied] the nature or basis of the experience into a meaningful whole" (DeSantis \& Ugarriza, 2000, p. 362).

Moreover, the researcher used an inductive data-driven approach to generate the themes from the raw data (Boyatzis, 1998), which meant focusing on the identification of themes that emerged from the data collected rather than seeking themes that would fit into pre-existing theoretical frameworks (Braun \& Clarke, 2006). Finally, to increase the trustworthiness of the study and themes found, the voices of outside experts were considered and consulted through a peer debriefing process to help the researcher see aspects that might have been overlooked during the thematic analysis process (Lincoln \& Guba, 1985; Nowell et al., 2017).

\section{Researcher's Positionality}

This study was conducted as collaborative research in which the participants acted as active collaborators in the study. In a collaborative or participatory inquiry, both the researcher and participants worked as equal collaborators, recognizing and valuing each other's expertise, insights, and contributions (Patton, 2002). Typically, the purpose of the participatory inquiry is to improve and change practices based on the study's findings (Creswell \& Poth, 2018). Besides, it was a learning process, as the participants learned "to think more systematically about what [they were] doing and [their] own relationship to those with whom [they] work" (Patton, 2002, p. 180). This collaborative aspect allowed the study to be completed with instead of on the participants (Kemmis \& Wilkinson, 1998). Consequently, Julio's and Henrique's voices were present throughout the research, mainly during the data collection and analysis processes, and collaborating with the final report (Creswell \& Poth, 2018). However, the two schoolteachers did not meet or interacted with one another during the research process; their contacts were limited to online interview meetings and online messages exchanged solely with the researcher.

The researcher, a Brazilian doctoral student in the United States, was responsible for designing and conceptualizing the study, based on her scholarship agenda and interests in multicultural education, culturally responsive teaching, and comparative international education studies. Julio was a public-school English teacher, and Henrique was a private-school Math teacher in Southeast Brazil. Both participants were responsible for granting access to and sharing information concerning their practice, curricular guidelines, and reports about the transition from traditional to distance learning during the COVID-19 pandemic school closure. 
At the time of the study, Julio worked in a public-school regionally awarded for best pedagogical practices during the quarantine. The best practices included revising pedagogical contents, materials sent to the local school district, surveys sent to families and communication with parents, and a well-structured schedule of internal activities, which could offer important insights for educators worldwide concerning distance learning for marginalized student populations. Similarly, Henrique worked in a private chain-school that consistently ranked among the top ten schools with the highest number of students approved in national college entrance exams. Also, the schools' best practices with online/distance learning during the pandemic were repeatedly praised and broadcasted by media outlets in Brazil. The information access granted by the participants and their collaboration during the research process was vital to help the researcher immerse herself with the data, becoming more familiar with the depth and breadth of the data and phenomenon under investigation (Braun \& Clarke, 2006).

\section{Case One: A Brazilian Public-School English Teacher}

Julio, a 34-year-old, White, middle-class male, was an English teacher of urban public schools in Southeast Brazil. He had a bachelor's in Portuguese/English, 13 years of teaching experience, out of which eight have been dedicated to teaching in public schools. At the time of the study, Julio worked at three public schools with students of first to sixth grades, ages six to 11. Each of his 15 classes - one $6^{\text {th }}$-grade, two $1^{\text {st }}, 2^{\text {nd }}$, and $5^{\text {th }}$ grades, and four $3^{\text {rd }}$ and $4^{\text {th }}$ grades - had approximately 30 students, and a total of 450 students in the 2020 school year.

Julio's workload and schedule were compatible with teachers' profile of non-core disciplines, such as English, in Brazilian primary schools, in which $40 \%$ of schoolteachers teach a single subject-matter, and 13.2\% teach to over ten classes of students (Carvalho, 2018). Despite the predominance of female teachers in Southeast Brazil, there has been an increase in male teachers in the last 15 years, corresponding to 17\% of the teaching force (Gatti \& Barretto, 2009). Over 1.8 million teachers work predominantly in urban schools, compared to approximately 327,000 in rural schools; moreover, $44.2 \%$ of the country's teaching force is concentrated in Southeast Brazil, where the study was conducted (Carvalho, 2018).

It is noteworthy that public-school teachers often work in precarious learning environments without adequate infrastructure to support teaching and learning. These professionals experience daily challenges of balancing outdated curricula and the pressure to adequate their lessons with technological advancements and deal with severe inequities while attending to marginalized student populations (Alvarenga et al., 2006; Souza, 2013). In Brazil, socioeconomic status is defined by family earnings and divided into five categories identified by letters-from A to Ethat correspond to the society's highest and lowest socioeconomic status, respectively. Over $90 \%$ of Julio's students were part of the lowest socioeconomic status in the country (letters D and E), corresponding to monthly family's earnings of up to 2,004 Brazilian Reals, approximately 383 American dollars - based on the exchange rate of USD 1 to BRL 5.70 (Banco Central do Brasil, 2020; Fundação Getúlio Vargas [FGV], 2014). In primary public-schools, $40.7 \%$ and $28.3 \%$ of students belong to the two poorest fifths of the population according to family earnings per capita, respectively (Instituto Brasileiro de Geografia e Estatística [IBGE], 2019).

Concerning race, $39.4 \%$ of Julio's students were White, $26.7 \%$ pardos, $10.3 \%$ black, and $26.6 \%$ did not declare their race in school admissions information. Pardo is a color/racial category in the Brazilian Census that, for over a century, described descendants of the mixture of Europeans and Sub-Saharan Africans and Europeans and Native Brazilians (IBGE, 2015). For the past 20 years, the Brazilian Census has stipulated that pardo represents more than the color of one's skin 
or ancestry; instead, it was a matter of self-identity, since all racial-ethnic identities are products of social interactions and are socially constructed (Petruccelli \& Saboia, 2013). However, it is significant that $26.6 \%$ of Julio's students did not indicate their race in their enrollment; the high percentage may indicate rejection of the given racial categories and sociocultural issues related to racism and historical discrimination of pardos and blacks in the country (Carvalho, 2018; INEP, 2009). Besides serving the most socioeconomically disadvantaged families, Julio's schools have recently received a large influx of transferred students from private schools who had lost their scholarships due to Brazil's economic hardships and instability.

Finally, when the Brazilian government announced the school closures due to the COVID19 pandemic in mid-March 2020, there was no official determination of how public-school teachers would transition to distance learning. The school activities and classes could be offered through digital platforms, videos, content posted on social media, radio, television, or printed materials (readings, exercises, projects, and activities) distributed to the students and their parents/caregivers (Tokarnia, 2020a). However, there were no determination or established control mechanisms to ensure that teachers would continue teaching online/remotely.

\section{Case Two: A Brazilian Private Chain-School Math Teacher}

Henrique, a 42-year-old, White, middle-class male, was a Math teacher of urban private chain-schools in Southeast Brazil. He had a bachelor's in Engineering with a Math teaching certification, four years of teaching experience, including private tutoring and teaching in private adult education schools. Henrique was a graduate student hoping to earn his master's in Mathematics in 2021. At the time of the study, Henrique worked at three schools of a 22-chain of private schools to students of fourth to $12^{\text {th }}$ grades, ages nine to 17 . Each of his 15 classes - one $5^{\text {th }}, 9^{\text {th }}, 10^{\text {th }}$ and $11^{\text {th }}$ grades, two $4^{\text {th }}, 6^{\text {th }}, 7^{\text {th }}$, and $8^{\text {th }}$ grades, and three $12^{\text {th }}$ grade classes - had 20 to 30 students, and a total of approximately 400 students in the 2020 school year.

Over $90 \%$ of Henrique's students were White, while the remaining were pardos or black. His students paid an average monthly tuition of 900 Brazilian Reals (approximately USD 170) plus pedagogical and instructional materials fees that summed to 2,000 Brazilian Reals (approximately USD 365). Thus, Henrique's students belonged to middle and upper-middle-class families-letters B and A-which correspond to monthly family's earnings of 8,641 to over 11,262 Brazilian Reals, respectively, and nearly 1,500 to 2,000 American dollars (FGV, 2014).

Besides high tuition rates, these private schools' admission requirements include extensive and rigid selective processes in which potential students take exams and interviews with the school principal and must present a good track academic record. Once admitted, the students have extensive class hours, from morning to early evening, particularly for high school students preparing for national college entrance exams. Thus, Henrique's students belonged to a Brazilian society segment that holds high standards for their children's education and competition for career and college preparation.

Like Julio, Henrique's workload and schedule were compatible with the teaching force profile of those teaching core disciplines like Math in Brazilian primary schools. Likewise, $68 \%$ of the teaching force has a Bachelor's degree in a field other than Education and earned a teaching certification, $87 \%$ work in urban schools, and $40.5 \%$ are concentrated in Southeast Brazil (Carvalho, 2018). 


\section{Findings}

The thematic analysis from the multiple sources of data resulted in three themes that expressed the experiences of both schoolteachers: (1) distant learning, (2) empathetic teaching vs. high-quality teaching, and (3) tech-savvy vs. technology-based teaching.

\section{Theme One: Distant Learning}

The first theme combined the similar views of Julio and Henrique with distant rather than distance learning. Regardless of their initiatives and efforts to promote and continue their classes online, both participants described disconnectedness with their students for different reasons. Julio reported the scarcity of resources and infrastructure provided by the school district that affected his ability to interact with his students directly and receive feedback about his instructional strategies' effectiveness. Despite aiming to establish connections with his students through playful videos, materials, and activities, imprinting his friendly identity and relationship with his students into the lessons, Julio faced significant setbacks as he could not warrant his students' access, much less understanding the content he provided.

The biggest challenge was the loss of human contact. As a teacher, I like and feel the need to observe my students' reactions and value exchanging ideas during classes. Technology contributes to classes, in-person and online, but it also makes the teacher-student relationship colder, more distant. (Julio)

Henrique also spoke of the disconnectedness with his students:

I miss the actual human contact. To look at my students, feel the energy from our interactions. Some things can only happen face-to-face. We know how the students are feeling or thinking just by looking at them, and sometimes all it takes is an encouraging look, a gesture, a pat on the back to establish a connection with them. And all of that was lost in online learning. They're there [online] but not with me. (Henrique)

Indeed, weaker connections between students and teachers have been identified as significant distance learning downsides (Moraes, 2010; Patto, 2013). Nonetheless, Julio indicated a much deeper gap that contributed to the distance he felt from his students.

Everything I developed was sent to the schools' principals. At no time did I interact with my students directly. The lack of infrastructure, policies, and legal support to protect teachers' and students' privacy, especially considering the students' age, limited my contact with them to slim interactions on a Facebook page created for the schools and a few messages I got in my professional email address.

Despite establishing distance learning national guidelines, Federal Decree 9.057 (Brasil, 2017) did not offer provisions concerning students' and teachers' privacy and interactions online. Moreover, no official policy or guidelines were enacted to determine how the teachers would send 
materials or communicate with their students and families during the pandemic. Also, no official determinations were made concerning whether the teachers would develop any lessons or materials for their students altogether during the school closures. As a matter of fact, the Brazilian Federal law $9.394 \$ 3$ (Brasil, 1996) established that school attendance for students and teachers is mandatory, except for distance learning. Thus, in Julio's case, because he had no direct contact with his students, he was requested to send the online lessons and videos to his principals to make the content available for the students online.

The school district's lack of support resulted in each school deciding what was best for their realities; so, "each school was on its own" (Julio), and the distribution of content was neither constant nor homogeneous. While some schools asked teachers to join newly created Facebook groups, using personal profiles to post videos and materials to students, others resorted to WhatsApp messaging, in which teachers had to use their cellphone numbers to communicate with students and parents. Julio's main concern stemmed from being requested to use his profile and phone number to interact with minors with no legal support to protect teachers' and students' interactions, an apprehension discussed in the literature concerning legal and policy questions of encouraging teachers and students to communicate and develop relationships in social media (Anctil, 2014). It is important to highlight that Julio's students were five to 12 years old and could not have their own social media profiles; moreover, teachers are often refrained from mixing their personal lives and social media profiles with students and their families. He said, "The truth is I think it's wrong to use social media to teach children online. I guess the schools resorted to that just for show," as an alternative to compensate for the lack of infrastructure provided by the school district and show society that the students were continuing to receive their education. In other words, social media was used by the school district administration, following orders from the city's mayor, as a diversion to hide the structural problems in public schools and the school district and ensure that teachers would not be punished with salary cuts for not being able to meet the demands of distance learning. For that reason, he added, "unfortunately, when it comes to public schools, everything is political." Consequently, Julio said, "I feel frustrated and sad, not because I expected any type of acknowledgment for doing my job, but for not knowing whether the students had access to, watched, or had any questions about the videos and materials I created."

Conversely, Henrique experienced disconnectedness in the absence of student contact, as his students did not turn on their cameras to interact with him or with one another. He said,

Though students and families were informed [by the schools] that they had to turn on their cameras during classes, they don't do it, especially my high school students. I'm always saying, 'guys, talk to me,' 'are you still there?' 'are you paying attention?' 'don't sleep, stay with me!'

Henrique also mentioned that students barely turned on their microphones to ask questions; usually, few students used the chat function or sent him emails with questions after the class. Thus, he stressed that the negative side of distance learning was the distance created between students and teachers, and among students themselves, which, consequently, created a distance in learning and understanding content:

It's difficult because [in face-to-face] we are looking at the students, we know when someone does not understand things. Online, it's almost impossible, especially with cameras and microphones off. I always tell them to speak up if they have questions because there's no other way for me to find out. 
He added that it was nearly impossible to know whether students were paying attention, using the computer for other activities online, or even doing something else at home. Therefore, whenever a student messaged Henrique with questions about content, he recorded videos and shared them with the whole class, anticipating that others might need further help.

\section{Theme Two: Empathetic Teaching vs. High-Quality Teaching}

The challenges of distance learning prompted the participants to find strategies to overcome the distance imposed by the online learning environment and other challenges students faced during school closures. While Julio emphasized the need for being empathetic to students' needs holistically, given the plights they experience in their everyday lives, Henrique's commitment was focused on ensuring the maintenance of high-quality education standards for his students online similar to the face-to-face environment. Next, each sub-theme discussed the divergent experiences of both participants.

\section{Empathetic Teaching}

In the face of the challenges imposed by school closures, Julio committed to an empathetic teaching style that drove him to seek and use resources he had at hand to maintain his classes and serve his students while still trying to attend to the curricular demands. Most importantly, he took into consideration the existing structural issues in the school district and public schools and adapted his weekly, face-to-face, one hour and 40 minutes class periods to each of his 15 classes to online videos, produced and edited by him and distributed to his students on social media. He said,

Based on the school district's English curriculum guidelines sent weekly, I'd prepare my lesson plans, materials, and videos. But it is important to highlight that I was never forced or required to produce any content for my students - whether I did it or not, it would've had no impact on my payroll. I did what I did thinking of nothing but my students-even though I knew many of them wouldn't have access [to the videos]. I felt I had to honor my commitment to my students and my profession.

Furthermore, Julio emphasized that, with the challenges imposed by COVID-19 and school closures, it would have been high-time for all stakeholders in education (including the government, school district, policymakers, and other sectors of society) to focus on compassion towards marginalized students and provide resources and alternatives to meet their needs. He said, "This is a critical time for the government and society to learn to think of others truly, to be more compassionate towards those in need. [The government and politicians'] excessive egocentrism and greed are evil for society." Julio described the hardships that the marginalized public-school students typically face that require schools to supply needs beyond education, like shelter and food (breakfast, lunch, and snack). Several of his examples depicted students with home life challenges that included but were not limited to poverty, abuse, addictions, and violence, including police brutality and conflicts among powerful drug-trafficking gangs, the police, and milíciasparamilitary outlaw groups comprised of active and retired police officers and firefighters - that take place in the favelas (slums) where they live. Julio added, 


\section{Halpern, C.}

At first, parents and students did not like the change [to distance learning]. Most parents and caregivers need the schools to be open and functioning to ensure that their kids' basic needs of food and shelter are met; you know, those needs they cannot provide.

For this reason, Julio realized that he would have to create activities and lessons that would help ease his students' pain, suffering, and stress during the school closures. In his view, such bad feelings and experiences resulted from the existing challenges students faced in their home lives that were augmented with the school closures during the COVID-19 pandemic. As Julio said, "My biggest concern was to avoid making dull videos and content because the reality of most of my students is delicate. I even tried to lighten-up the grammatical content for the most advanced classes as much as I could."

Julio's lessons, activities, and videos were planned according to the curricular guidelines available to all public-school teachers at the school district and organized with his "target audience and content in mind which meant taking into consideration developmentally and age-appropriate content." His lessons included crossword puzzles, music, sing-alongs, dance, games (trivia), funny, playful characters, and movie scenes familiar to the students and their interests, without losing sight of the curricular guidelines for each week's lessons. His choice of lightening-up the content was a strategy to help students "have fun while being overloaded with materials from other teachers and disciplines, and endure all the difficulties they face daily with their families." His focus was on student engagement through play-based activities:

To make the content more fun and play-based, I turned to YouTube channels—which I already used in my face-to-face classes-created lessons on Microsoft Sway and mixed them up with a little grammatical content. Nothing too hard. My idea was that if I did something fun, students could watch the videos over and over until the next one was sent.

Julio had a deep commitment to supplying his students' needs that transcended the classroom walls, which required him to think of his students' lack of parental involvement or support, challenging family and financial lives, and plights brought by the pandemic.

\section{High-Quality Teaching}

Henrique said that, initially, all teachers and school administrators did not know how the transition to online/distance learning would look. He described his initial reaction to the transition as a mix of "anxiety in the face of the unknown, uncertainty, and insecurity." However, he highlighted school administrators' fundamental role and collaborative efforts to smooth transition to online/distance learning for teachers, students, parents, and staff. Their actions were described as "helpful, supportive, nurturing, and attentive to the human factor needed in the face of a significant change in teaching and learning." Consequently, he developed a positive outlook shared by him and his colleagues: "If [teaching online] was new to me, it was also new to students, parents, schools, and teachers. So, in our schools, we developed a strong mindset of making sure everything would work as closely to face-to-face learning as possible."

As a result, the schools' administrators provided a support system that included consistent communication with parents and students to ensure that they would continue to receive the same high-quality education they were used to, and teachers and staff knew they would have the best infrastructure, support, and resources to continue working online. Moreover, the schools created 
an IT task force team to develop means to support online learning, with room for adjustments based on teachers, students, and parents' feedback. "We've had amazing feedback from everyone. Even the parents say we're doing something outstanding. Our schools were even on the news!" He attributed the success to the administrators' and teachers' integration and collaboration, IT support, and family engagement. Furthermore, the online classes were hosted on a similar schedule to the students' regular face-to-face classes to stay consistent with their daily routines and parents' expectations. Henrique's 50-minute periods were transformed into short-focused 25-minute classes and activities online.

Despite the successful transition, initial challenges to teaching online related to Henrique's uneasiness recording lessons. "At first, everything was strange and awkward because you're literally teaching to a camera, interacting with a machine." This experience made him unsure whether his students would like his lessons or follow through with the new format. He was concerned for achieving a balance between "not planning a dull class and sleep-inducing videos on the one hand, and not feeling like [he] was becoming a YouTuber, on the other hand." Henrique's concern resided in discussions of whether education - particularly online-should be equated to entertainment rather than content. Repeatedly, he mentioned his commitment to developing his students' critical thinking, their ability to solve problems, and question content avoiding rote memorization. "These YouTuber-like teachers seem to think they're at the center stage of education, that they're the stars when students should be at the center of their education. We, as educators, should be there to guide them in this process."

Concerning the teachers' planning and teaching, Henrique mentioned that, at first, the school's pedagogical division organized the materials, exercises, lesson plans, and even PowerPoint presentations to send teachers and help them transition to online learning. He said,

Initially, the pedagogical division was ahead of everything. Now that we got the hang of it, we have total freedom to teach beyond the material, propose different activities, and use online strategies based on the curricular guidelines and expectations.

Consequently, Henrique was able to innovate his classes by adding more technological tools to improve education, as depicted in the following theme.

\section{Theme Three: Tech-Savvy² vs. Technology-Based Teaching}

Though Julio and Henrique had similar views on the role and importance of technology for teaching, particularly during the COVID-19 pandemic, they had different experiences using and applying technology to their instruction. While Julio relied on his tech-savviness and familiarity with using social media, Henrique was more confident about implementing technology into his teaching. Henrique saw the school closures as a "golden opportunity" to apply his technology knowledge to his online classes to engage his students. Each of the following sub-themes depict each of the participants' experiences with technology in their teaching.

\footnotetext{
${ }^{2}$ Tech-savvy is defined by someone who is proficient or well-informed with the use of modern technology.
} 


\section{Halpern, C.}

\section{Tech-Savvy}

Julio claimed not having issues transitioning from face-to-face to distance learning, saying that he had the necessary tools to do so (i.e., notebook and internet access). Julio relied on his familiarity with technology that he used in his leisure time to prepare his videos and materials, emphasizing his knowledge of using social media and messaging apps like Facebook, YouTube, and WhatsApp. However, he admitted,

If this were to happen again, I'd have to invest in training to learn to teach online. You know, it's one thing to be tech-savvy and using the internet for my own entertainment online, and a completely different thing to know which technology is best to use to teach my students.

Though Julio's school district made a partnership with Microsoft in late August so that teachers and students would use Microsoft Teams for classes and meetings, he attributed the hindrances to implement it to "teachers' digital illiteracy." Julio repeatedly emphasized the importance of including technology skills in teaching and teacher education programs. However, he was equally concerned with the lack of laws and regulations to protect teachers when teaching online, and teachers' unreadiness and students' resources to use technology.

\section{Technology-Based Teaching}

Henrique's experience depicted his commitment to implement technology into teaching, which made his transition to online learning enjoyable, not challenging. These unprecedented times inspired him to use his skills and education to his teaching and interaction with students: "Before the pandemic, I insisted that educators in Brazil were swimming against the current, demanding students to turn off their phones and avoid bringing their laptops or tablets to class." So, pandemic and school closures became an opportunity to rethink education and the role of technology in teaching and learning. He added, "educators must shift their perceptions on cellphones and tablets in the classrooms from enemies or distractions to seeing them as our allies in student learning." More importantly, Henrique was overjoyed and motivated to transform the unprecedented shift to teaching online into an opportunity to apply his knowledge and skills acquired during his master's research on technology applied to teaching Mathematics. He said,

What motivated me to go beyond the school's instructional materials was the opportunity to use more technology in favor of my instruction and students. This is what my research is about, and it's something students and teachers are not used to.

He highlighted the use of Kahoot to engage students in fast, competitive quizzes on Mathematical foundational concepts, as well as GeoGebra, an interactive algebra, geometry, calculus, and statistics application for teaching and learning mathematics online. Henrique said he could be using these applications and software in his face-to-face classes if schools were committed to including technology in the classroom, rather than banning them as a cause of students' distraction. The pandemic allowed him to introduce his students to broader educational possibilities online to better understand the content, get more excited about Mathematics, and use cellphones, laptops, and tablets to benefit learning and achieve pedagogical goals. As a result, Henrique witnessed a significant change in student engagement and interaction: 
I went from having students who were bored of staring at a non-interesting computer screen for three to five hours a day to increased student engagement when I started implementing [technology] skills to my classes. They seem more interested, lively, and participate a lot more using the apps and software I introduced them to. They seem to be more excited about Math, which we know it's a significant plus in education.

Henrique emphasized that these apps and software allowed students to interact more rather than sit staring at a screen looking without opportunities to engage with one another, like in their face-to-face classes. His efforts to implement his technological knowledge to instruction benefitted students' online learning during the pandemic.

\section{Discussion}

It was noteworthy the role of participatory inquiry in this study. As the participants learned to think systematically about their practice and were introduced to the process of evidence-based inquiry, the findings also produced insights that inspired them to change their teaching practices and views of technology in teaching. In this sense, this project's collaborative aspect enabled the participants to become co-researchers in contributing to the data collection and analysis and offering insights to the final report (Patton, 2002). One evidence of the benefits and the sense of ownership resulted from the experience of collaborative/participatory inquiry was that both participants became interested in moving forward their educational degrees, with one of them seeking a master's program and the other applying for a competitive selective process for a doctorate program. Concerning the method and analysis, the thematic analysis offered comprehensive considerations about Brazilian teachers' experiences with and perceptions of the transition to distance/online learning providing transferability rather than generalizable findings (Vaismoradi \& Snelgrove, 2019). As Stake (1995) proposed, the findings can offer lessons learned from the cases to be applied to similar contexts and settings.

Regarding the theme of distant learning, it can be questioned whether the distance between students and teachers already existed and became more apparent in the context of distance/online education with school closures during the COVID-19 pandemic. The physical, face-to-face learning environment does not safeguard that a teacher-learner relationship will benefit students' learning process and achievement compared to online learning. It is possible that distance learning brought to light something that may have always existed, that is, gaps, failures, barriers, and absence in the teacher-learner relationship (Garbe et al., 2020; Patto, 2013). In this sense, the findings of this study may indicate to what extent a structural gap already existed between teachers and students before the pandemic that may have affected the learning experiences and interactions in online learning. Perhaps the traditional face-to-face learning environment camouflaged certain deficiencies in education created by these interactions' inherent distractions.

Another aspect evident in the first theme was the teachers' dispositions to overcome distance/online learning challenges. Despite the relevance of Julio's initiatives to deal with the scarcity of resources and support from his school district, the findings indicated that he was acting on his own; if it were not for his commitment to his students, there would have been no collective action plan to provide alternatives to attend to the marginalized school population he taught. Notably, one of Julio's school was awarded for best practices in transitioning to online learning. Thus, considering that it was up to the teachers whether to produce and share content with their students online or even attempt to interact with them on social media, one is left to wonder what 
will happen to students of schools that had no classes to ensure the continuity of their education during the pandemic school closures. Everyone was on their own; Julio, other public-school teachers, the government and its contradictory directives to schools and the population. Julio's experiences reflected the context of crisis that extrapolated issues that already existed. This is particularly relevant considering the population Julio taught, marginalized for their race, poverty, and other Brazilian societal issues that placed these children at a considerable disadvantage when competing with their White, middle- and upper-middle-class peers for equitable opportunities in education and life. In other words, in Julio's experience, the distance already existed with the lack of support and resources and teachers' distance from their students' needs. Julio tried to overcome a gap within the Brazilian education system's structural issues in public schools, the deep-rooted inequities, and the absence of social justice towards marginalized populations (Moraes, 2011). Thus, it may seem disproportionate to blame distance learning for education failures, notably being the only alternative during the school closures and with all the challenges the pandemic imposed on people's lives worldwide.

None of the participants mentioned the inclusion of the COVID-19 pandemic topic into lessons or try to give their students space to discuss the subject and how it might be affecting them. Julio was aware of his students' daily challenges and how they might have been augmented with the pandemic leading him to create content to lighten-up his students' lives. Whereas Henrique repeatedly mentioned that he was not aware that his students were going through any issues related to the pandemic either in their education or family/personal lives. It does not necessarily mean that Henrique's students did not have any issues during the pandemic, but the topic did not seem relevant to be approached in class or conversations with students.

Thus, little was discussed regarding the promotion of a realist, authentic education (Halpern, 2017) in the face of a tragedy; the cold, distant relationships could have been the only acceptable reactions given the circumstances and uncertainties. Social distance was the recommendation to prevent the transmission of the virus that could have affected all relationships (Viner et al., 2020), including teachers and students online. Perhaps, if education was not so centered in following and meeting curricular guidelines and was more place-based and focused on the students' experiences (Halpern, 2018; Sobel, 2013), the issues related to the pandemic could have become topics during classes, as a way to give students space to share their perspectives, hopes, fears, and find support in one another. The overemphasis in meeting curricular guidelines in the face of a pandemic seemed like the teachers were trying to deviate the subject as if in "normal" circumstances with videos to help distract and entertain students, rather than making it a part of their lessons. Perhaps this attitude contributed to the distance felt by both participants concerning the relationship with their students. How can one concentrate in "regular" classes with everything that was going on and displayed broadly in media outlets about the pandemic worldwide?

Furthermore, the fact that both schoolteachers did not seem to have time to approach the pandemic and their students' experiences in their online classes, believing they had strict curricular plans to adhere, may indicate a need to revisit the overall purpose of education, particularly during the unprecedented global crisis. If the purpose of education is solely the adherence to curricular standards disregarding the effects of the pandemic in human life and societal issues, then education will be reduced to dry guidelines and checklists (Halpern, 2018; Parkay et al., 2014). Instead, education should be about developing students' global awareness and educating them to use critical and creative thinking to solve real-life situations. Such $21^{\text {st }}$-century skills can and should be applied to mathematics and English (Parkay et al., 2014; Toheri et al., 2020).

Paradoxically, the unifying factor was, precisely, technology, regardless of how teachers and students accessed it; otherwise, the isolation during the pandemic would have increased. In this 
sense, what was perceived as the factor that drove students and teachers distant became the bridge, the connection among them during the school closures. Without it, no contact would have been possible. In this sense, Julio's efforts were commendable in helping his students; however, his empathetic character was a personal disposition, independent of his teacher education/training or the school district and administration's structure, that is, elements beyond his control or ability to change. Teachers and principals commonly show disinterest in engaging with students using digital tools, which results in their resistance in adapting their lessons to use technology (Anctil, 2014). Conversely, Henrique's experience revealed the importance of integration efforts at the school administration level to overcome the challenges of teaching online, a commitment that went beyond personal dispositions and empathy but efforts that materialized in actions that maintained students' education and classes going. In other words, while Henrique's experience was one of collective, collaborative efforts that allowed him to add his technology training to his lessons, Julio relied on himself and his creativity to provide for his students.

Concerning the use of technology in distance learning, its inclusion was imposed and became the reality of teachers and students who transitioned to the online environment. Nonetheless, the school closure during the pandemic opened up avenues to adapt teachers' and students' daily lives to and create possibilities in online learning, allowing educators to rethink the use and role of technology in education. Indeed, $21^{\text {st }}$-century schools need $21^{\text {st }}$-century technology and skills, and the school closures during the COVID-19 pandemic demanded that technological integration in instruction, affecting teachers and students in their teaching and learning processes and socially (Prensky, 2014).

However, it also highlighted the need to educate teachers on incorporating technology into their lessons without fear or resistance to change (Prensky, 2014). While Julio implemented technology and online resources based on his familiarity with social media and online applications, Henrique saw this opportunity to implement his training and research in educational technology into his classes. Perhaps the unprecedented times of the pandemic that forced education to become fully online from K-12 to postsecondary education will work as a transition to a new model in education with more interaction and shared experiences among teachers, students, and exchanged contents worldwide. However, structural changes are needed to follow such trends and changes, particularly considering marginalized populations and their several plights in social, economic, and cultural disadvantages that make technological and communication advancements applied to education seem unrealistic and shortsighted.

\section{Conclusion, Recommendation, and Implications}

The purpose of the study to investigate the perspectives and experiences of two schoolteachers while teaching remotely during the school closures imposed by the COVID-19 pandemic was met. Despite working under distinct circumstances, including the schools' leadership, infrastructure, and resources available to continue teaching online, and attending to different student populations, the participants had similar experiences with the distance they felt in their interactions with students. In addition, the participants' perceptions and experiences with the use of technology in education and their commitment to teaching and learning during the pandemic, diverged. These differences could have been affected by the leadership support (or lack thereof) in transitioning to distance learning, as well as the characteristics of the student population taught by each of the participants. While Julio worked with students marginalized by racial discrimination and socioeconomic issues who studied at public schools that lacked appropriate resources to teach online, Henrique relied on the collaborative and supportive actions of his schools' leadership to 
successfully transition to distance learning. As a result, Julio resorted to sending play-based and fun content to his students, whereas Henrique focused on adhering to curricular guidelines to continue his students' education.

It is also noteworthy that the research, like the participants' experiences, was also carried out virtually amidst the pandemic. The researcher, a doctoral student in the United States, conducted the study online with two schoolteachers that lived and worked in Brazil. Indeed, the pandemic impacted several activities imposing the transition to the virtual environment, including research. Thus, despite the notable disadvantages of carrying out research from a distance and online, the researcher could take advantage of the situation and explore the meanings of the participants' experiences teaching online.

Besides the benefits of presenting the findings of the study, the research allowed the participants to have a voice, that their perspectives mattered, and helped them feel that they were not alone during the pandemic. Consequently, they expressed gratitude and felt encouraged to continue their work; moreover, they continued sharing materials, news, and experiences after the manuscript was submitted to publication. In this sense, the significance of this study was the impact it had on the participants and the perspectives they developed about themselves as teachers and the work they did as a result of their participation in the research process. Such impact was only possible due to the methodology chosen; while misconceptions about the value of focusing on a small number of cases exist, case studies offer the opportunity to investigate the phenomenon indepth and thoroughly (Creswell \& Poth, 2018). In this sense, while case studies' findings cannot be generalizable, the lessons learned from them can be applied to other contexts or settings (Stake, 1995).

Nonetheless, a recommendation for future studies would be to investigate the perspectives of schoolteachers from other parts of the country, as well as their experiences being back to faceto-face learning after the school closures imposed by the pandemic. Other recommendations would be to examine the perspectives of school leaders, students, and parents; those could add other dimensions to enrich Julio's and Henrique's perspectives teaching remotely in the pandemic.

This study's implications consist of a call to improve Brazil's teacher education programs to include technology-driven strategies and a more considerable emphasis on inclusive and culturally relevant curriculum and instruction that serves each student population's needs. Indeed, multicultural and culturally responsive teaching skills are fundamental in different levels of teacher education programs (Halpern \& Aydin, 2020). The study's findings also call for changes in education policies that include access to the internet and technology and alternative plans for curriculum and instruction adaptability and flexibility to be applied in the event of other critical situations similar to a global pandemic. As proposed by UNICEF Brazil (2020), in the event of a global pandemic like COVID-19, it is crucial to ensure free internet access to vulnerable families and children and expand the use of technologies in education to radio and television to broadcast educational contents to children and adolescents that do not have internet access.

Finally, school closures' broad impact on students' academic outcomes and well-being are yet to be known. Though Kuhfeld et al. (2020) projected that missing school interactions for long periods, such as the months of school closures during the pandemic, will significantly impact student achievement in the long-term, still educators and scholars are faced with more questions than answers to help improve the experiences of schoolteachers, staff, administrators, students, and families worldwide during the pandemic and its following effects. The COVID-19 pandemic emphasized systemic and deeply rooted inequity and inequality issues in education in Brazil. On the other hand, the pandemic can be seen as a learning opportunity that has opened up doors to educators and scholars to employ their expertise and improve educational services, broadly aiming for the public good and students' needs. Above all, it is notable what educators can do to adapt and 
reinvent themselves in unprecedented times to continue serving their students despite the absence of ideal support and resources that highlight these professionals' value and their role in improving society.

\section{References}

Alvarenga, E., Vieira, E. P., \& Lima, M. M. (2006). Os impactos das políticas educacionais brasileira no trabalho docente [The impacts of Brazilian educational policies in the teaching profession]. Proceedings of the Seminário da Redestrado UERJ.

Anctil, E. J. (2014). 21st century schools require media literate leaders. In F. W. Parkay, E. J. Anctil, \& G. Hass, Curriculum leadership: Readings for developing quality educational programs (10th ed., pp. 109-114). Pearson.

Banco Central do Brasil (2020). Cotações e boletins: USD Dólar [Quotations and bulletins: USD Dollar]. https://www.bcb.gov.br/estabilidadefinanceira/historicocotacoes

Boyatzis, R. (1998). Transforming qualitative information: Thematic analysis and code development. SAGE Publishing.

BRASIL. (1996, December 20). Lei Federal 9.394. Ministério da Educação. http://www.planalto.gov.br/ccivil_03/leis/19394.htm

BRASIL. (2005, December 20). Decreto Federal 5.622. Ministério da Educação. http://www.planalto.gov.br/ccivil_03/_Ato2015-2018/2017/Decreto/D9057.htm\#art24

BRASIL. (2017, May 25). Decreto Federal 9.057. Ministério da Educação. http://www.planalto.gov.br/ccivil_03/_Ato2015-2018/2017/Decreto/D9057.htm\#art24

Braun, V., \& Clarke, V. (2006). Using thematic analysis in psychology. Qualitative Research in Psychology, 3, 77-101. https://doi.org/10.1191/1478088706qp063oa

Carvalho, M. R. V. (2018). Perfil do professor da educação básica [Schoolteachers' profile]. Série documental: Relatos de pesquisa, 41. http://portal.inep.gov.br/informacao-da-publicacao//asset_publisher/6JYIsGMAMkW1/document/id/1473981

Creswell, J. W. (2014). Research design: Qualitative, quantitative, and mixed methods approaches (4th ed.) SAGE Publishing.

Creswell, J. W., \& Poth, C. N. (2018). Qualitative inquiry and research design: Choosing among five approaches (4th ed.). SAGE Publishing.

Denzin, N.K. (1989). Interpretive Interactionism. SAGE Publications.

DeSantis, L., \& Ugarriza, D. (2000). The concept of theme as used in qualitative nursing research. Western Journal of Nursing Research, 22, 351-372. https://doi.org/10.1177/019394590002200308

Fundação Getúlio Vargas [FGV] (2014). Faixa de renda familiar [Range of family earning]. https://cps.fgv.br/qual-faixa-de-renda-familiar-das-classes

Garbe, A., Ogurlu, U., Logan, N., \& Cook, P. (2020). Parents' Experiences with Remote Education during COVID-19 School Closures. American Journal of Qualitative Research, 4(3), 4565. https://doi.org/10.29333/ajqr/8471

Gatti, B., \& Barretto, E. S. (2009). Professores do Brasil: Impasses e desafios [Teachers in Brazil: Impasses and challenges]. UNESCO.

Guimarães, C. (2010, August 27). Como tirar seu diploma pela internet [How to get your degree on the internet]. Época. http://revistaepoca.globo.com/Revista/Epoca/0,,EMI16671315259,00-COMO+TIRAR+SEU+DIPLOMA+PELA+INTERNET.html

Halpern, C. (2018). The gears of the hidden curriculum revisited. Journal of Curriculum Theorizing, 33(1), 40-44. 
Halpern, C. (2017). Book review: In search of understanding: The case for constructivist classrooms (2nd ed.). American Journal of Qualitative Research, 1(1), 32-36.

Halpern, C., \& Aydin, H. (2020). The light in their eyes: Creating a multicultural education course for doctoral level students. Journal for Multicultural Education, 35(2), 85-100. https://doi.org.10.1108/JME-11-2019-0079

Instituto Brasileiro de Geografia e Estatística [IBGE] (2015). Definição de raça [Racial definition]. http://www.consultaesic.cgu.gov.br/busca/_layouts/15/DetalhePedido/DetalhePedido.aspx ?nup=03950001396201556

Instituto Brasileiro de Geografia e Estatística [IBGE] (2019). Síntese de indicadores sociais: Uma análise das condições de vida da população brasileira [Synthesis of social indicators: An analysis of Brazilian population life conditions]. Estudos \& Pesquisas, Informação $\begin{array}{lll}\text { Demográfica } & e & \text { Socioeconômica, }\end{array} 4$. https://biblioteca.ibge.gov.br/visualizacao/livros/liv101678.pdf

Instituto Nacional de Estudos e Pesquisas Educacionais Anísio Teixeira [INEP] (2009). Estudo exploratório sobre o professor brasileiro: Com base nos resultados do Censo Escolar da Educação Básica 2007 [Exploratory study of Brazilian teachers: Based on the results of the Education Census 2007]. http://portal.mec.gov.br/dmdocuments/estudoprofessor.pdf

Instituto Nacional de Estudos e Pesquisas Educacionais Anísio Teixeira [INEP] (2019). Censo escolar [Education Census]. http://portal.inep.gov.br/artigo//asset_publisher/B4AQV9zFY7Bv/content/dados-do-censo-escolar-mais-de-77-dasescolas-brasileiras-de-ensino-fundamental-anos-finais-sao-publicas/21206

Kemmis, S., \& Wilkinson, M. (1998). Participatory action research and the study of practice. In B. Atweh, S. Kemmis, \& P. Weeks (Eds.), Action research in practice: Partnerships for social justice in education (pp. 21-36). Routledge.

Kuhfeld, M., Soland, J., Tarasawa, B., Johnson, A., Ruzek, E., \& Liu, J. (2020). Projecting the potential impact of COVID-19 school closures on academic achievement. Educational Researcher, 49(8), 549-565. https://doi.org/10.3102/0013189X20965918

Lincoln, Y., \& Guba, E. G. (1985). Naturalistic inquiry. SAGE Publishing.

Lu, S. (2020). School + family community learning model of PE course under COVID-19 epidemic situation. International Journal of Emerging Technologies in Learning, 15(18), 218-233. https://doi.org/10.3991/ijet.v15i18.16439

Lynch, M. (2020). E-learning during a global pandemic. Asian Journal of Distance Education, 15(1). https://www.asianjde.org/ojs/index.php/AsianJDE/article/view/457

Merriam, S. B. (1998). Qualitative research and case study applications in education. Jossey-Bass.

Modelski, D., Giraffa, L. M. M., \& Casartelli, A. O. (2019). Tecnologias digitais, formação docente e práticas pedagógicas [Digital Technologies, teacher education and pedagogical practices]. Educação e Pesquisa, 45, 1-17 https://doi.org/10.1590/S1678-4634201945180201

Moraes, R. C. C. (2010). Educação a distância e efeitos em cadeia [Distance learning and its effects]. Cadernos de Pesquisa, 40(140), 547-559. https://www.scielo.br/pdf/cp/v40n140/a1240140.pdf

Moraes, V. F. (2011). Desvantages do EaD [Disadvantages of distance learning]. Proceedings of the Congresso Nacional Universidade, EAD e Software Livre. http://www.textolivre.pro.br/blog/?p=1013

Ncube, S., \& Motalenyane, A. M. (2020). Social distancing, cultural and psychological effects on learners in a rural setting in Zimbabwe. Journal of Ethnic and Cultural Studies, 7(3), 200209. http://dx.doi.org/10.29333/ejecs/503 
Nowell, L. S., Norris, J. M., White, D. E., \& Moules, N. J. (2017). Thematic analysis: Striving to meet the trustworthiness criteria. International Journal of Qualitative Methods, 16(1), 113. https://doi.org/10.1177/1609406917733847

Oliveira, E. (2020, June 9). Quase 40\% dos alunos de escolas públicas não têm computador ou tablet em casa, aponta estudo [Nearly $40 \%$ of public-school students have no computers or tables at home]. G1. https://g1.globo.com/educacao/noticia/2020/06/09/quase-40percentdos-alunos-de-escolas-publicas-nao-tem-computador-ou-tablet-em-casa-apontaestudo.ghtml

Parkay, F. W., Anctil, E. J., \& Hass, G. (2014). Curriculum leadership: Readings for developing quality educational programs (10th ed.). Pearson.

Patto, M. H. S. (2013). O ensino a distância e a falência da educação [Distance learning and the decay of education]. Educação e Pesquisa, 39(2), 303-318. https://www.scielo.br/pdf/ep/v39n2/a02v39n2.pdf

Patton, M. Q. (2002). Qualitative research and evaluation methods (3rd ed.). SAGE Publishing.

Petruccelli, J. L., \& Saboia, A. L. (Org.) (2013). Características étnico-raciais da população: Classificações e identidades [Population's ethnic-racial characteristics: Classifications and identities]. Estudos \& Análises: Informação demográfica e socioeconômica, 2. https://biblioteca.ibge.gov.br/visualizacao/livros/liv63405.pdf

Prensky, M. (2014). Adopt and adapt: Twenty-first-century schools need twenty-first-century technology. In F. W. Parkay, E. J. Anctil, \& G. Hass, Curriculum leadership: Readings for developing quality educational programs (10th ed., pp. 386-390). Pearson.

Roller, M. R., \& Lavrakas, P. J. (2015). Applied qualitative research design: A total quality framework approach. The Guilford Press.

Sobel, D. (2013). Place-based education: Connecting classrooms and communities (2nd ed.). Orion.

Souza, A. R. (2013). O professor da educação básica no Brasil: Identidade e trabalho [Basic education teachers in Brazil: Identity and work]. Educar em. Revista, 48, 53-74. https://www.scielo.br/pdf/er/n48/n48a05.pdf

Souza, P. N. P. (2008). A revolução da EaD [The revolution of distance learning]. Diário de Cuiabá. http://diariodecuiaba.com.br/artigos/a-revolucao-da-ead/328024

Stake, R. E. (1995). The art of case study research. SAGE Publishing.

Stake, R. E. (2005). Qualitative case studies. In N. K. Denzin \& Y. S. Lincoln (Eds.), The SAGE Handbook of Qualitative Research (3rd ed., pp. 443-454). SAGE Publications.

Tenente, L. (2020, May 26). 30\% dos domicílios no Brasil não têm acesso à internet: Veja números que mostram dificuldades no ensino à distância [30\% of Brazilian homes have no internet access: Numbers reveal challenges of online learning]. G1. https://g1.globo.com/educacao/noticia/2020/05/26/66percent-dos-brasileiros-de-9-a-17anos-nao-acessam-a-internet-em-casa-veja-numeros-que-mostram-dificuldades-noensino-a-distancia.ghtml

Toheri, Winarso, W., \& Haqq, A. A. (2020). Where exactly for enhance critical and creative thinking: The use of problem posing or contextual learning. European Journal of Educational Research, 9(2), 877-887. https://files.eric.ed.gov/fulltext/EJ1250377.pdf

Tokarnia, M. (2020a, April 28). CNE autoriza atividades não presenciais em todas as etapas de ensino [CNE authorizes online activities for all education stages]. Agência Brasil. https://agenciabrasil.ebc.com.br/educacao/noticia/2020-04/cne-autoriza-atividades-naopresenciais-em-todas-etapas-de-ensino 
Tokarnia, M. (2020b, May 17). Brasil tem 4,8 milhões de crianças e adolescentes sem internet em casa [In Brazil, 4.8 million children and adolescents do not have internet access at home]. Agência Brasil. https://agenciabrasil.ebc.com.br/educacao/noticia/2020-05/brasil-tem-48milhoes-de-criancas-e-adolescentes-sem-internet-em-casa

UNESCO (2020, May 13). Reopening schools: When, where and how? https://en.unesco.org/news/reopening-schools-when-where-and-how

UNICEF Brasil (2020, May 12). UNICEF alerta: Garantir acesso livre à internet para famílias e crianças vulneráveis é essencial na resposta à COVID-19 [UNICEF alerts: It is essential to ensure free internet access to vulnerable children and families to respond to COVID-19 challenges]. https://www.unicef.org/brazil/comunicados-de-imprensa/unicef-alertaessencial-garantir-acesso-livre-a-internet-para-familias-e-criancas-vulneraveis

Vaismoradi, M., \& Snelgrove, S. (2019). Theme in qualitative content analysis and thematic analysis. Forum: Qualitative Social Research, 20(3), 1-14. https://doi.org/10.17169/fqs20.3.3376

Viner, R. M., Russell, S. J., Croker, H., Packer, J., Ward, J., Stansfield, C., Mytton, O., Bonell, C., $\&$ Booy, R. (2020). School closure and management practices during coronavirus outbreaks including COVID-19: A rapid systematic review. Lancet Child and Adolescent Health, 4, 397-404. https://doi.org/10.1016/S2352-4642(20)30095-X

Yin, R. K. (2005). Case study research: Design and methods. SAGE Publications.

\section{Notes on Contributor}

Clarisse Halpern is a doctoral student in the Department of Curriculum, Instruction, and Culture at Florida Gulf Coast University, USA. Her scholarship focuses on multicultural and multilingual education, culturally responsive teaching and cultural competence in teacher preparation programs, immigration issues in education, international students and faculty, and international comparative education studies. She has taught English as a second language and undergraduate courses on English to speakers of other languages. Recently, she has served as a committee member of FGCU's campus internationalization contributing to improving the recruitment and retention of international students. 